\title{
Przyczynek do diagnostyki różnicowej bezdechów śródnocnych, wspótistniejących w zaburzeniach czynnościowych układu stomatognatycznego
}

\section{A contribution to the differential diagnosis of sleep apnoea coexisting with functional disorders of the stomatognathic system}

\author{
Halina Ey-Chmielewska $\bowtie$ \\ Pomorski Uniwersytet Medyczny w Szczecnie, Zakład Protetyki Stomatologicznej, al. Powstańców Wlkp. 72, 70-111 Szczecin \\ $\triangle$ halina.ey-chmielewska@pum.edu.pl
}

\begin{abstract}
Functional disorders of the stomatognathic system (temporomandibular joint syndrome - TMJ-syndrome) represent a growing diagnostic and therapeutic problem. One of the coexisting symptoms, especially in advanced stages of temporomandibular joint disorders, is sleep apnoea.

The aim of this paper is to present two simple diagnostic methods that can help differentiate the causes of sleep apnoea. The
\end{abstract}

first method relates to verification of the breathing pattern. The second one is the measurement of neck circumference. The presented methods are straightforward and minimally invasive. They can be supportive of the differential diagnosis of causes of sleep apnoea in the course of functional disorders of TMJ-syndrome.

Keywords: sleep apnoea; diagnostics; functional disorders of the masticatory system.

\author{
ABSTRAKT \\ Zaburzenia czynnościowe układu stomatognatycznego stanowią \\ coraz większy problem diagnostyczny i terapeutyczny. Jednym \\ z współistniejących objawów, zwłaszcza w zaawansowanych \\ postaciach zaburzeń czynności stawów skroniowo-żuchwowych, \\ są bezdechy śródnocne. \\ Celem pracy było przedstawienie dwóch prostych metod dia- \\ gnostycznych, które mogą pomóc w różnicowaniu przyczyn
}

bezdechów śródnocnych. Pierwsza metoda dotyczy weryfikacji sposobu oddychania, druga - pomiaru obwodu szyi. Przedstawione metody są proste i mało inwazyjne. Mogą być działaniem wspomagającym diagnostykę różnicową przyczyn powstawania bezdechu śródsennego w przebiegu zaburzeń czynnościowych. Słowa kluczowe: bezdech śródnocny; diagnostyka; zaburzenia czynnościowe narządu żucia.

\section{WSTĘP}

Zaburzenia czynnościowe układu stomatognatycznego są coraz większym problemem diagnostycznym i terapeutycznym $[1,2$ 3, 4, 5]. O znaczeniu tego zjawiska świadczy liczba publikacji ukazujących się nie tylko w czasopismach stomatologicznych oraz referatów poświęcanych tej tematyce na konferencjach naukowych $[1,6,7,8,9]$. Jednym z współistniejących objawów, zwłaszcza w zaawansowanych postaciach zaburzeń czynności stawów skroniowo-żuchwowych, są bezdechy śródnocne [2, $3,4,8,9,10,11,12]$. Problemem, z którym stykają się lekarze dentyści, jest diagnostyka różnicowa w przypadku terapii zaburzeń czynnościowych układu stomatognatycznego powikłanych bezdechami śródnocnymi [9, 13, 14, 15, 16, 17]. Podczas oddychania torem nosowym powietrze przechodzi przez jamy nosowe, w których znajdują się przegroda nosa oraz małżowiny nosowe pokryte błoną śluzową [8]. Istotna jest konieczność określenia różnicowania przyczyn powstawania zaburzeń toru oddechowego $[18,19]$.
Celem pracy było przedstawienie prostych metod diagnostycznych, które mogą pomóc w planowaniu terapii oraz w różnicowaniu przyczyn:

I. Metoda określenia przyczyn zaburzenia przepływu powietrza przez jamę nosowo-gardłową.

II. Metoda oceny obwodu szyi, która może wspomagać diagnostykę różnicową. Stosowana tylko u osób dorosłych.

\section{METODA I}

Oddychanie to proces wymiany gazów pomiędzy organizmem a jego środowiskiem, zapewniający dopływ tlenu do tkanek i stałe usuwanie dwutlenku węgla. Prawidłowe oddychanie odbywa się torem nosowo-gardłowym. Powietrze przy wdechu przechodzi przez jamę nosową, gdzie dochodzi do jego ogrzania oraz oczyszczenia przez znajdujące się w jamie nosowej włoski i komórki z rzęskami wychwytującymi nieczystości, a także nawilżanie przez znajdujący się śluz. Następnie 
poprzez gardło, krtań, tchawicę i oskrzela powietrze dociera do płuc.

Test - należy polecić pacjentowi, by zamknął usta i oddychał przez nos.

Jeżeli pacjent odczuwa przeszkodę, wówczas należy skierować go do lekarza laryngologa, aby sprawdzić, czy nie ma obrzęku błony śluzowej jam nosowych, polipów, skrzywienia przegrody lub przerostu małżowin nosowych.

Jeżeli pacjent zgłasza, że ma uczucie zapadania się nozdrzy, należy spróbować $\mathrm{w}$ trakcie testu podnieść je szpatułką. Jeżeli poprawia się tor oddechowy, należy zastosować metody pozwalające na rozszerzenie nozdrzy.

Przyczyna: Zmiany spowodowane zwężeniem jam nosowych lub zapadające się nozdrza. Przy oddychaniu torem ustnym, w trakcie wdechu powietrze uderza w tylną część gardła i wprowadza w wibrację miękkie części podniebienia, języczek i tylną ścianę gardzieli, powodując odgłos chrapania. Dlatego istotne jest określenie przyczyn powodujących utrudnione oddychanie przez usta.

Test - należy polecić pacjentowi, by wykonał wdech torem ustnym, po czym trzeba sprawdzić, czy w trakcie tej czynności pacjent może zachrapać. Następnie należy polecić pacjentowi zamknięcie ust i ponowne wykonanie próby wdechu.

Przyczyna: Jeżeli przy zamkniętych ustach pacjent nie chrapie, to znaczy, że przyczyną chrapania jest otwieranie ust w trakcie snu. Należy zatem w terapii uwzględnić metody zapobiegające otwieraniu ust podczas snu.

Test - należy polecić pacjentowi, by wysunął język i przytrzymał go zębami. Następnym krokiem jest wykonanie czynności oddychania torem ustnym. Jeżeli nie powstaje charakterystyczny dźwięk chrapania, to znaczy, że tylko w trakcie snu, kiedy język zapada się wraz z przemieszczającą się żuchwą ku tyłowi, dochodzi do blokowania prawidłowego przepływu powietrza i tym samym pojawia się wibracja powietrza słyszana jako chrapanie.

Przyczyna: Opadający język przesuwający żuchwę ku tyłowi. Należy w terapii uwzględnić takie postępowanie, które będzie zapobiegało dotylnemu przemieszczaniu się żuchwy.

\section{METODA II}

Powiększanie się obwodu szyi najczęściej spowodowane jest otyłością. Dlatego w takich przypadkach konieczne jest zbadanie przyczyn otyłości i skierowanie do właściwego lekarza specjalisty. Jednym ze wskaźników otyłości jest obwód szyi. Otyłość powodująca powiększenie obwodu szyi może być przyczyną zaburzenia toru oddechowego. Określenie skorygowanego obwodu szyi może być również prostym wskaźnikiem mającym pomocnicze znaczenie w diagnostyce zespołu bezdechu śródsennego. Pozwala na określenie ryzyka jego wystąpienia u osób otyłych. Jest to bardzo istotne w terapii osób dorosłych. Ocena obwodu szyi może być metodą wspomagającą diagnostykę różnicową zaburzeń oddechowych w przebiegu dysfunkcji narządu żucia.

Wyznaczenie skorygowanego obwodu szyi polega na dodaniu do faktycznego obwodu szyi:

+4 - w przypadku występowania nadciśnienia tętniczego,

+3 - w przypadkach chrapania lub zaobserwowanego nocnego dławienia się lub duszenia.

Wystąpienie ryzyka zespołu bezdechu śródsennego uznaje się za możliwe w przypadku, kiedy skorygowany obwód wynosi:

poniżej $43 \mathrm{~cm}$ - jako ryzyko małe,

43-48 cm - jako ryzyko umiarkowane,

powyżej $48 \mathrm{~cm}$ - jako ryzyko duże.

\section{OMÓWIENIE ZASADNOŚCI ZAPROPONOWANYCH METOD DIAGNOSTYCZNYCH}

U niektórych osób podczas snu mięśnie gardła i języka wiotczeją częściowo lub całkowicie, rozluźniają się mięśnie podniebienia miękkiego, co powoduje blokowanie przepływu powietrza przez drogi oddechowe $[4,18,19]$. Jest to zakłócenie drogi toru oddechowego. Oddech staje się często zbyt płytki i nieregularny, bywa wysilony i głośny. Czasem dochodzi do zatrzymania oddechu. Tym samym upośledzone zostają procesy wentylacyjne organizmu. Niedotlenienie organizmu sprawia, że człowiek, który ma nierównomierny oddech, źle sypia, chrapie podczas snu, krzyczy, często budzi się, a następnego dnia bywa zmęczony, nieuważny i rozkojarzony [2, 19, 20]. Podłożem upośledzonej czynności oddechowej mogą być wady rozwojowe, odmienności budowy anatomicznej, urazy, czynniki organiczne, infekcje układu oddechowego oraz niedostateczna drożność jam nosa [3, 4]. Występowanie bezdechów nocnych o różnym nasileniu, jako objawów współistniejących w zaburzeniach czynnościowych układu stomatognatycznego, obserwuje się coraz częściej i mają one złożone podłoże $[2,4,9,12]$. Chrapanie jest jednym z objawów pojawiających się w przypadku zmiany stosunku przestrzennego między żuchwą a szczęką, którego przyczyną jest najczęściej dotylne przemieszczenie żuchwy. Przemieszczenie to może być spowodowane różnymi czynnikami $[8,10]$. Jednym z nich może być utrata stref podparcia spowodowana obniżeniem zwarcia lub utratą zębów. Przemieszczenie żuchwy ku tyłowi może być również spowodowane wzmożonym napięciem mięśni żwaczy $[10,11,12,15,21]$, a także występuje często w trakcie leczenia wad ortodontycznych za pomocą aparatów stałych. W postępowaniu stomatologicznym terapii zaburzeń czynnościowych powikłanych bezdechami śródnocnymi stosuje się różnego rodzaju szyny zgryzowe i aparaty odciążające oraz szyny stabilizujące. Umożliwiają one uzyskanie i utrzymanie prawidłowego położenia żuchwy względem szczęki, a tym samym prawidłową stabilizację krążków stawowych i głów wyrostków kłykciowych żuchwy [14,16]. Wykonane aparaty ortopedyczne i stomatologiczne mogą być stosowane jako deprogramatory, tak jak szyny NTI, a także przygotowane ex tempore przy pacjencie $[6,7,13,14,22]$. Porównując uzyskane 
wyniki z danymi innych autorów, można stwierdzić, że poprzez zastosowanie szyn własnej modyfikacji uzyskano lepszą adaptację u pacjentów, tym samym skrócono okres terapii [15, 22].

\section{PODSUMOWANIE}

Przedstawione metody są proste i mało inwazyjne, mogą być działaniem wspomagającym diagnostykę różnicową przyczyn powstawania bezdechu śródsennego w przebiegu zaburzeń czynnościowych układu stomatognatycznego. Tym samym mogą mieć wpływ na zastosowanie odpowiedniej terapii dostosowanej indywidualnie, wspomagającej leczenie zaburzeń czynnościowych w układzie stomatognatycznym.

\section{PIŚMIENNICTWO}

1. Almeida FR, Bittencourt LR, Tsuiki S, Lowe AA, Tufik S. Effects of mandibular posture on obstructive sleep apnea severity and the temporomandibular joint in patients fitted with an oral appliance. Sleep 2002;25:505-13.

2. International classification of sleep disorders: diagnostic and coding manual. 2nd ed. Westchester (IL): American Academy of Sleep Medicine; 2005.

3. Kuna ST, Remmers JE. Anatomy and physiology of upper airway obstruc tion. In: Kryger MH, Roth T, Dement WC, editors. Principles and practice of sleep medicine. 3rd ed. Philadelphia: W.B. Saunders; 2000. p. 840-58.

4. Johns MW. Reliability and factor analysis of the Epworth Sleepiness Scale. Sleep 1992;15(4):376-81.

5. Gola R, Chossegros C, Orthlieb JD, Lepetre C, Ulmer E. Otologic manifestations of the pain dysfunction syndrome of the stomatognathic system. Rev Stomatol Chir Maxillofac 1992;93(4):224-30.

6. Tsuiki S, Almeida FR, Bhalla PS, Lowe AA, Fleetham JA. Supine-dependent changes in upper airway size in awake obstructive sleep apnea patients. Sleep Breath 2003;7:43-50.

7. L'Estrange PR, Battaggel JM, Harkness B, Spratley MH, Nolan PJ, Jorgensen GI. A method of studying adaptive changes of the oropharynx to variation in mandibular position in patients with obstructive sleep apnoea. J Oral Rehabil 1996;3:699-711.

8. Ryan CF, Love LL, Peat D, Fleetham JA, Lowe AA. Mandibular advancement oral appliance therapy for obstructive sleep apnoea: effect on awake calibre of the velopharynx. Thorax 1999;4:972-7.

9. Lowe AA. Oral appliances for sleep breathing disorders. In: Kryger MH, Roth T, Dement WC, editors. Principles and practice of sleep medicine. 3rd ed. Philadelphia: W.B. Saunders; 2000. p. 929-39.

10. Fanali S, Cerri A. The otoneurological and dental picture of Costen's paindysfunction syndrome. Minerva Stomatol 1993;42(1-2):37-43.

11. Harari D, Redlich M, Miri S, Hamud T, Gross M. The effect of mouth breathing versus nasal breathing on dentofacial and craniofacial development in orthodontic patients. Laryngoscope 2010;120(10):2089-93.

12. Dempsey JA, Veasey SC, Morgan BJ, O’Donnell CP. Pathophysiology of sleep apnea. Physiol Rev 2010;90(1):47-112.

13. Ey-Chmielewska H, Sobolewska E, Frączak B, Polak-Majcher D. Therapeutic splints as a method of procedure in the treatment of painful temporomandibular joint dysfunction. Mag Stom 2009;3:30-4.

14. Fabjański P, Ślusarska A. Wybrane aspekty leczenia protetycznego zaburzeń narządu żucia. Protet Stomatol 2000;50(4):195-7.

15. Kogut G, Kowolek A. Functional disturbances of the masticatory apparatus - diagnosis and treatment. Med Rehab 2006;10(1):44-56.

16. Rawlison A. Self-determined jaw relations for edentulous temporomandibular pain-dysfunction syndrome. Eur J Prosthodont Restor Dent 1997;2:43-45.

17. Cofta Sz. Zespół obturacyjnego bezdechu śródsennego - współczesne poglądy na diagnostykę i terapię. Przew Lek 2007, 9:10.

18. Pły waczewski R, Brzecka A, Bielicki P, Czajkowska-Malinowska M, Cofta Sz, Jonczak L, et al. Zalecenia Polskiego Towarzystwa Chorób Płuc dotyczące rozpoznawania i leczenia zaburzeń oddychania w czasie snu (ZOCS) u dorosłych. Pneumonol Alergol Pol 2013;81(3):221-58.

19. Connect Sz. Zespół obturacyjnego bezdechu śródsennego - współczesne poglądy na diagnostykę i terapię. Przew Lek 2007;9(101):76-83.

20. Chruściel-Nogalska M, Kozak M, Ey-Chmielewska H. Zespół obturacyjnego bezdechu podczas snu - podstawy diagnostyki i leczenia. Dent Forum 2015;43(1):65-9.

21. Ey-Chmielewska H, Teul I, Lorkowski J. Functional disorders of the temporomandibular joints as a factor responsible for sleep apnoea. Ann Acad Med Stetin 2014;60(2):65-8.

22. Ey-Chmielewska H, Teul I, Lorkowski J. Increasing the upper airway space using oral appliances in patients with mild sleep apnoea caused by stomatognathic dysfunctions. Ann Acad Med Stetin 2014;60(2):74-9. 